\title{
Competency framework validation: application in textile industry DOI: 10.35530/IT.072.05.1810
}

\section{ABSTRACT - REZUMAT \\ Competency framework validation: application in textile industry}

Previous research on the subject has reported that competency-based management has a constructive impact on organizational and employees' performance. One way of presenting human resource competencies is through a formal framework. This study is part of a project to validate a scientifically developed competency framework and assesses the prospects of its application in specific industrial sectors of Pakistan. This methodological work was carried out with background learning in the first phase and a survey was conducted in second phase involving practitioners and experts from the textile industry. Their responses were used to validate the face and content of the framework. Participants were given a presentation on the methodology followed in developing the competency framework and provided a questionnaire for feedback. Out of 75 participants from the textile industry, the majority were from human resource, sales, marketing, information technology, finance, operations, engineering, quality and logistics at managerial level. Participants validated the framework design and contents without suggesting any changes. This study gave confidence about the framework, its development methodology, its format and presentation before bringing in practice.

Keywords: competence, framework, methodological study, survey, practitioners and experts in textile, validation

Validarea cadrului competențelor: aplicarea acestuia în domeniul textil

Cercetările anterioare asupra acestui subiect au arătat că managementul bazat pe competențe are un impact constructiv asupra performanței organizaționale și a angajaților. O modalitate de prezentare a competențelor resurselor umane se realizează pe baza unui cadru formal. Acest studiu face parte dintr-un proiect de validare a unui cadru de competențe dezvoltat științific și evaluează perspectivele aplicării acestuia în sectoarele industriale specifice din Pakistan. Această lucrare metodologică a fost realizată în prima fază pe baza documentării și în a doua fază printr-un sondaj implicând practicieni și experți din industria textilă. Răspunsurile lor au fost utilizate pentru a valida aspectul și conținutul cadrului competențelor. Participanților li s-a prezentat metodologia urmată în dezvoltarea cadrului competențelor și aceștia au furnizat date într-un chestionar pentru feedback. Din cei 75 de participanți din industria textilă, majoritatea provine din resurse umane, vânzări, marketing, tehnologia informației, finanțe, operațiuni, inginerie, calitate și logistică la nivel managerial. Participanții au validat aspectul și conținutul cadrului, fără a sugera modificări. Acest studiu a oferit încredere în acest cadru, în metodologia sa de dezvoltare, formatul și prezentarea acestuia înainte de a fi pus în practică.

Cuvinte-cheie: competență, cadru, studiu metodologic, sondaj, practicieni și experți în textile, validare

\section{INTRODUCTION}

Though the term organizational capability and competence (or competency) is new and fashionable [1], the concept is old. Competency-based management has reported a positive influence on organizational and employees' performance [2]. Competencies are, therefore, essential for meeting performance standards and achieving important results in an explicit work role in any organization [3]. However, a mere listing of competencies has more value for its users if similar competencies are grouped to form a framework [4]. The practice of competency frameworks may appeal to scholars and practitioners to serve as the foundation for many human resource development activities. Among its advantages is that the employees know precisely which competencies are required for success and how they will be evaluated [5]. Unfortunately, the use of competency frameworks is often hindered because of conceptual ambiguity, a lack of methodological rigor in the development of such systems, and psychometric issues [6]. This challenge could be met:

- If the framework is developed based on some established work regarding jobs' classification, roles and functions.

- If the framework is formalized by involving a group of experts from various professions.

- If scientific methods are used to reduce subjectivity.

The development of competency frameworks starts with the identification of required competencies and excerpts from literature, study of the documents and conversing. The process is furthered by acquiring consensus from the experts for validity [7].

There are a variety of competency frameworks available mostly developed to cater to particular needs or are job-specific and perceived as knowledge-specific and task-specific [8]. Some generic frameworks are moreover presented with varied shapes and formats 
from having no structure or just a collection of competencies or structured by the relationship among the containing competencies [9].

The need for a framework exists, which is generic and could be utilized without significant modifications as the core competencies remain the same in any managerial position across organizations and countries [10]. This generic framework could be implemented in any industrial or business sector.

Competency frameworks ideally should be validated before being put into use to provide a sound platform upon which various HR applications may be based [11]. This study was conducted to validate the framework for its outlook and presentation. Also, the framework was validated for having relevant content and the likelihood of its usefulness in the textile sector of Pakistan at various stages of the human resource lifespan.

The results of the study are promising in a manner that the face and content validity of the framework in subject is established. The presentation and arrangement of information in the framework make it pragmatic to apply. The framework is accepted to be appropriate for application in the textile industry for recruitment, performance evaluation, training need analysis and career planning.

\section{METHODOLOGY}

In this study, methodology employing a questionnaire was used to validate a recently developed competency framework. The subjects were professionals working in textile who could be benefited from the application of the framework. Textile is one of the major contributors of earning foreign exchange for Pakistan. The industry has been facing incremental changes and global competition requiring a commensurate set of managerial skills [12]. The key to the success of any organization in present-day competition lies in its human resource proficient in identifying distinctive and ingenious solutions to the challenges [13]. The study was conducted in the industrial hub of Karachi city inviting 75 managers and senior managers working in the area of human resource, sales, marketing, information technology, finance, operations, engineering, quality and logistics from the textile sector.

The participants were provided a questionnaire in two parts. The first part comprising of five questions, was to face validate the framework and asses its utilization prospects. Participants were also to rate the chances of competency framework utilization, methodology undertaken, presentation of the framework and its comprehensiveness in the textile sector's perspective of Pakistan.

The second part compromising of ten questions were about knowing how the framework contents are appropriate in terms of their coverage of the subject. The questions asked were related to the appropriateness of job title, key roles, key performance indicators, job responsibilities, and their linkage with competencies, progressive levels and weight-ages of competencies. 25 professionals in five groups of five each and in three sessions discussed the matter to provide uninfluenced feedback of their own.

\section{Inclusion criteria}

The participants were required to fulfil the following criteria: (i) must be currently employed and working on a managerial position in the textile sector; (ii) should be a graduate, with an exception of diploma in apparel design; (iii) should have a minimum of ten years of professional experience; (iv) should have an official concern regarding selection and recruitment, deployment and promotion, development planning of subordinates and/or performance evaluation.

\section{Number of respondents per framework}

Table 1 shows the qualification/ area of expertise with a number of professionals working in the textile sector who participated in validation exercise. The number of participants shows that there are no less than 7 participants (cost accountancy and business management in finance taken together) to provide feedback for a framework of any particular job (framework was available for eight jobs). For face validity, researchers recommend to have at least seven to ten people. For content validity, it should not be less than 2 [14].

Table 1

\begin{tabular}{|c|l|c|}
\hline \multicolumn{2}{|c|}{ AREA OF EXPERTISE FOR PROFESSIONALS WHO } \\
PARTICIPATED \\
\hline $\begin{array}{c}\text { Sr. } \\
\text { no. }\end{array}$ & Education/Area of expertise in & $\begin{array}{c}\text { Number of } \\
\text { participants }\end{array}$ \\
\hline 1 & Business management, finance & 8 \\
\hline 2 & $\begin{array}{l}\text { Business management, } \\
\text { marketing }\end{array}$ & 12 \\
\hline 3 & $\begin{array}{l}\text { Business management, supply } \\
\text { chain }\end{array}$ & 7 \\
\hline 4 & Cost accountancy & 2 \\
\hline 5 & $\begin{array}{l}\text { Engineering (mechanical, } \\
\text { electrical, textile }\end{array}$ & 7 \\
\hline 6 & Human resource management & 13 \\
\hline 7 & Information technology & 10 \\
\hline 8 & Science (physics and chemistry) & 9 \\
\hline 9 & Apparel design & 7 \\
\hline & Total & 75 \\
\hline
\end{tabular}

* Three of the textile engineers worked in production and two in quality.

\section{Sampling methodology}

It was targeted to connect with as many professionals in textile as possible through HR and textile fora. The number of such professionals living in Karachi is a big population of unknown size. The sampling technique based on Cochran's formula was used to determine the sample (number of participants) size [15]. Cochran's formula was applied:

$$
n_{0}=\frac{z^{2} p q}{e^{2}}
$$


where $n_{0}$ is sample size, $p$ - estimated proportion of population which has the attribute (to attend), $q=1-p$, $e-$ error or desired level of precision and $Z-$ standard normal random variable.

It was assumed that $5 \%$ of the entire population would attend $(p)$. We will calculate the sample size with $5 \%$ precision $(e)$ and at $95 \%$ confidence level ( $Z=1.96)$.

$$
n_{0}=\left[(1.96)^{2} \times 0.05 \times 0.95\right] /(0.05)^{2}=72.99 \approx 73
$$

\section{Administration of questionnaire}

Details about the methodology and scientific tools used in developing the competency framework were briefed. The presentation was followed by a questionanswer session and collecting feedback on a questionnaire. This questionnaire was previously tested for internal consistency based on 32 HR professionals' feedback and calculating Cronbachavalue, which came out to be 0.82 .

Modus operandi of the session was also briefed and instructions were given on the questionnaire. The participants were additionally asked to solicit their feedback considering questions: (i) do you have any suggestions for improving the contents in terms of information or format? (ii) do you have any new item/information which you would like to add? No suggestions came forward requiring any review or change in the framework and its contents. The whole methodology is presented in figure 1 .

\section{Face validity}

355 out of 375 possible responses (98.40\%) are on higher side as shown in table 2 and plotted in figure 2 , thus validating its outlook and presentation.

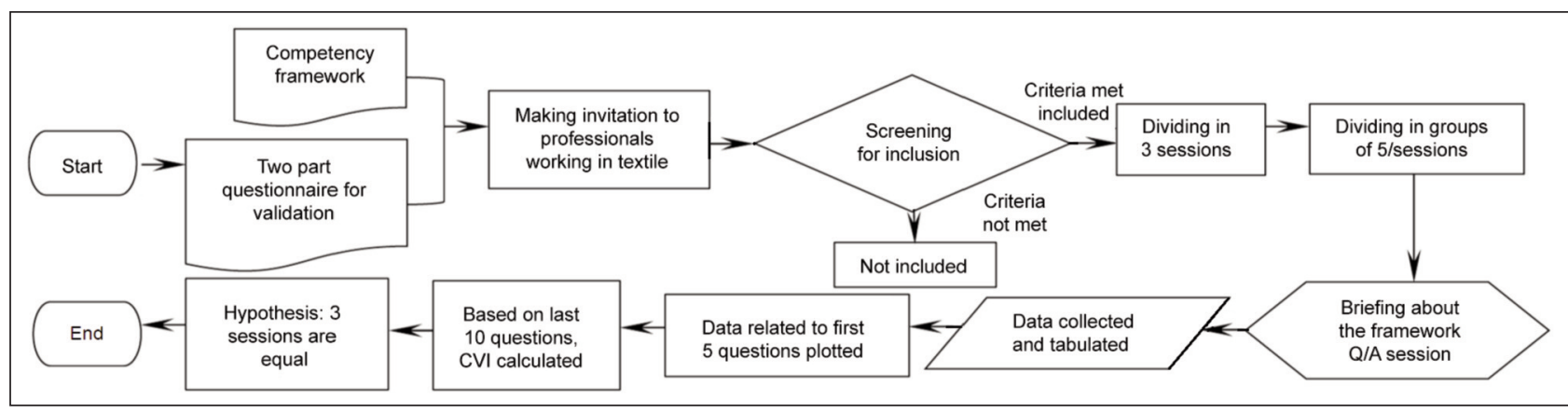

Fig. 1. Methodology followed for this study

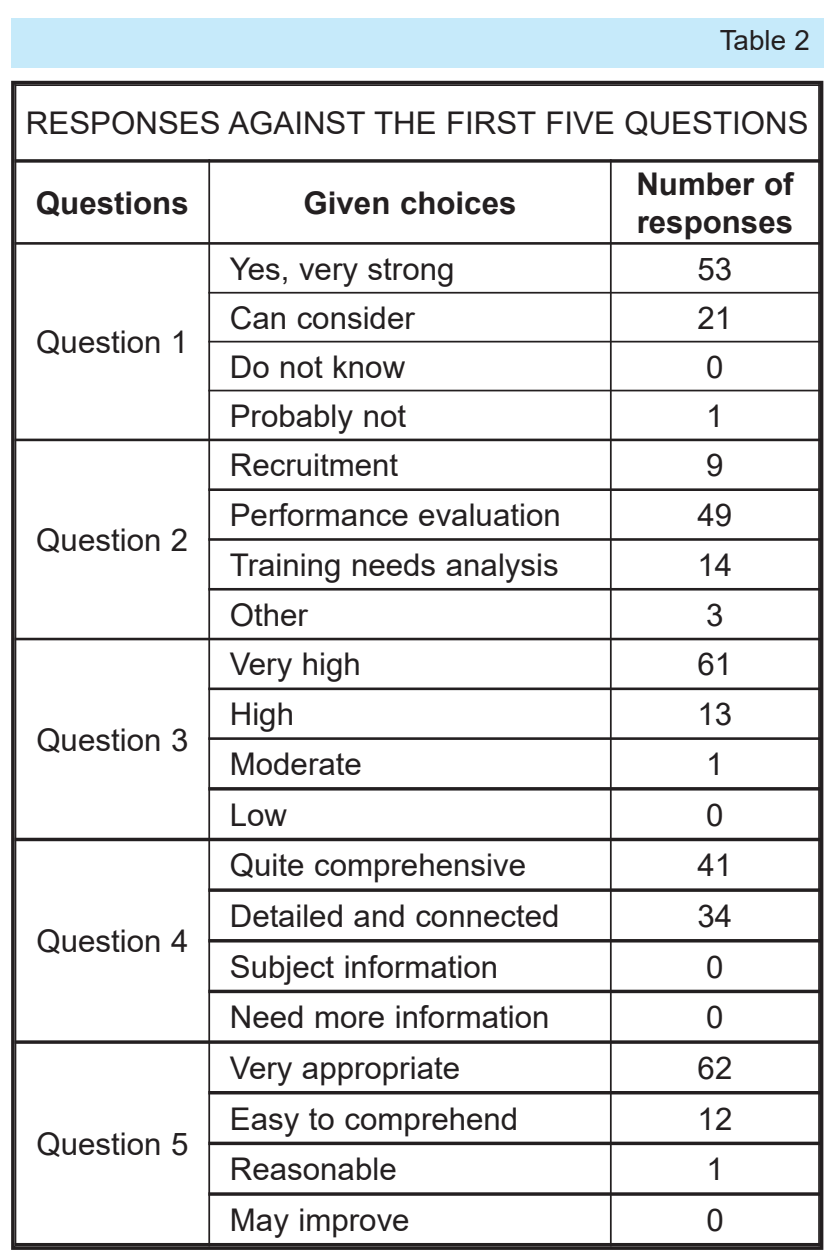

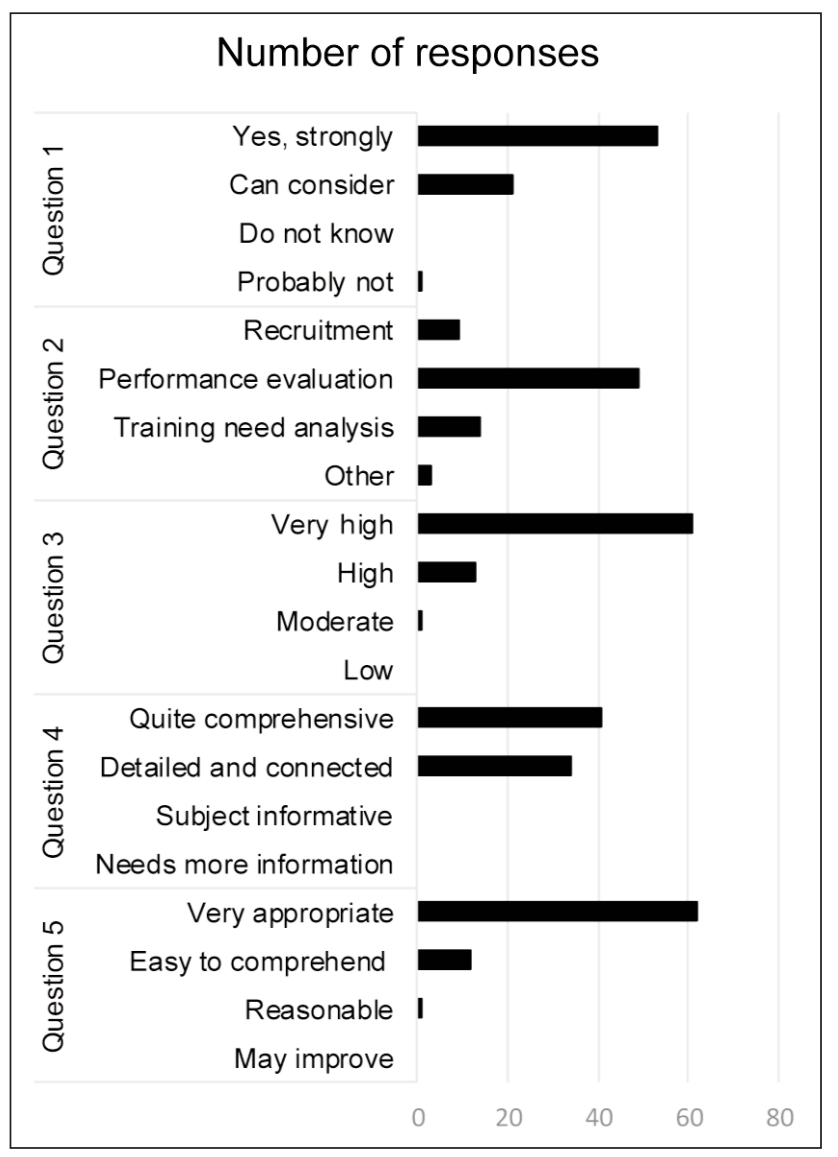

Fig. 2. Responses against first five questions 


\section{Content validity}

Average of the item-level content validity index (S-CVI/Avg) was calculated for each question asked. An S-CVI reaching $90 \%$ qualifies the instrument to be content valid [28]. Table 3 for sessions 1 to 3 respec- tively, show the respondents' feedback data and the calculation of CVI. Each session was independent with a mix of professionals. The data, Scale Level Content Validity Index (S-CVI), were discrete values. It was appropriate to evaluate that all sessions

\begin{tabular}{|c|c|c|c|c|c|c|c|c|c|c|c|c|c|c|c|c|c|c|c|c|c|c|c|c|c|c|c|c|c|c|c|c|c|c|c|}
\hline \multicolumn{36}{|c|}{ AVERAGE OF THE ITEM-LEVEL CONTENT VALIDITY INDEX } \\
\hline & 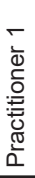 & 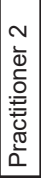 & 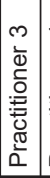 & 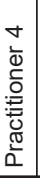 & 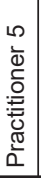 & 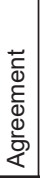 & 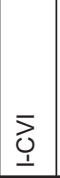 & 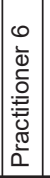 & 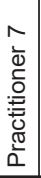 & 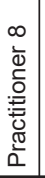 & 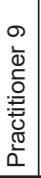 & 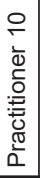 & 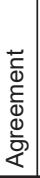 & 恿 & 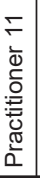 & 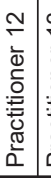 & 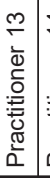 & 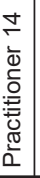 & 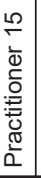 & 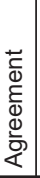 & $\underset{1}{\rangle_{1}}$ & 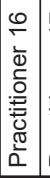 & 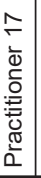 & 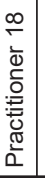 & 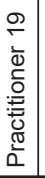 & 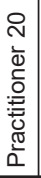 & 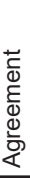 & $\underset{\substack{>\\
}}{ }$ & 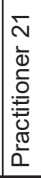 & 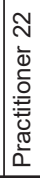 & 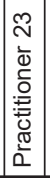 & 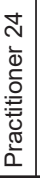 & 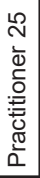 & 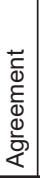 & $\underset{1}{>}$ \\
\hline & 4 & 3 & 4 & 4 & 4 & 4 & 0.80 & 3 & 4 & 4 & 4 & 4 & 4 & 0.80 & 4 & 4 & 4 & 4 & 3 & 4 & 0.80 & 4 & 4 & 4 & 4 & 4 & 5 & 1.00 & 4 & 4 & 4 & 4 & 4 & 5 & 1.00 \\
\hline Que & 3 & 4 & 3 & 4 & 4 & 3 & 0.60 & 4 & 4 & 4 & 4 & 4 & 5 & 1.00 & 7 & 4 & 4 & 4 & 3 & 4 & 0.80 & 4 & 4 & 4 & 4 & 4 & 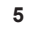 & 1.00 & 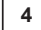 & 4 & 4 & 3 & 4 & 4 & 0.80 \\
\hline Que & 4 & 4 & 4 & 4 & 4 & 5 & 1.00 & 4 & 4 & 4 & 4 & 4 & 5 & 1.00 & 4 & 4 & 4 & 4 & 4 & 5 & 1.00 & 4 & 4 & 4 & 4 & 4 & 5 & 1.00 & 4 & 4 & 4 & 4 & 4 & 5 & 1.00 \\
\hline Question 9 & 4 & 4 & 4 & 4 & 4 & 5 & 1.00 & 4 & 4 & 4 & 4 & 4 & 5 & 1.00 & 4 & 4 & 4 & 4 & 4 & 5 & 1.00 & 4 & 4 & & 4 & 4 & 5 & 1.00 & 4 & 4 & 4 & 4 & 4 & 5 & 1.00 \\
\hline Ques & 4 & 3 & 4 & 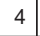 & 4 & 4 & 0.80 & 3 & 4 & 4 & 4 & 4 & 4 & 0.80 & 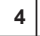 & 4 & 4 & 4 & 4 & 5 & 1.00 & 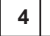 & 4 & 4 & 1 & 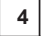 & 5 & 1.00 & 4 & 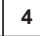 & 4 & 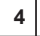 & 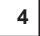 & 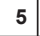 & 1.00 \\
\hline Que & 4 & 4 & 4 & 4 & 4 & 5 & 1.00 & 4 & 4 & 4 & 4 & 4 & 5 & 1.00 & 4 & 4 & 4 & 4 & 4 & 5 & 1.00 & 4 & 4 & 4 & 4 & 4 & 5 & 1.00 & 4 & 4 & & 4 & 4 & 4 & 0.80 \\
\hline Question 12 & 4 & 4 & 4 & 4 & 4 & 5 & 1.00 & 4 & 4 & 4 & 4 & 4 & 5 & 1.00 & 4 & 4 & 4 & 4 & 3 & 4 & 0.80 & 4 & 4 & 4 & 4 & 4 & 5 & 1.00 & 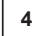 & 4 & 4 & 4 & 4 & 5 & 1.00 \\
\hline Ques & 4 & 4 & 4 & 4 & 4 & 5 & 1.00 & 4 & 4 & 4 & 4 & 4 & 5 & 1.00 & 4 & 4 & 4 & 4 & 4 & 5 & 1.00 & 4 & 4 & 4 & 4 & 4 & ? & 1.00 & 4 & 4 & 4 & 4 & 4 & 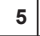 & 1.00 \\
\hline Question 14 & 4 & 4 & 4 & 4 & 4 & 5 & 1.00 & 4 & 4 & 4 & 4 & 4 & 5 & 1.00 & 4 & 4 & 4 & 4 & 4 & 5 & 1.00 & 4 & 4 & 4 & 4 & 4 & 5 & 1.00 & 4 & 4 & 4 & 4 & 4 & 5 & 1.00 \\
\hline Question 15 & 4 & 4 & 4 & 4 & 4 & 5 & 1.00 & 4 & 4 & 4 & 4 & 4 & 5 & 1.00 & 4 & 4 & 4 & 4 & 4 & 5 & 1.00 & 4 & 4 & 4 & 4 & 4 & 5 & 1.00 & 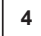 & 4 & 4 & 4 & 4 & 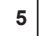 & 1.00 \\
\hline \multicolumn{6}{|c|}{$\mathrm{CVI} / \mathrm{Av}$} & & 0.92 & \multicolumn{5}{|c|}{ S-CVI/Avg } & & 0.96 & \multicolumn{5}{|c|}{ S-CVI/Avg } & & 0.94 & \multicolumn{5}{|c|}{ S-CVI/Avg } & & 1.00 & \multicolumn{5}{|c|}{ S-CVI/Avg } & & 0.96 \\
\hline
\end{tabular}

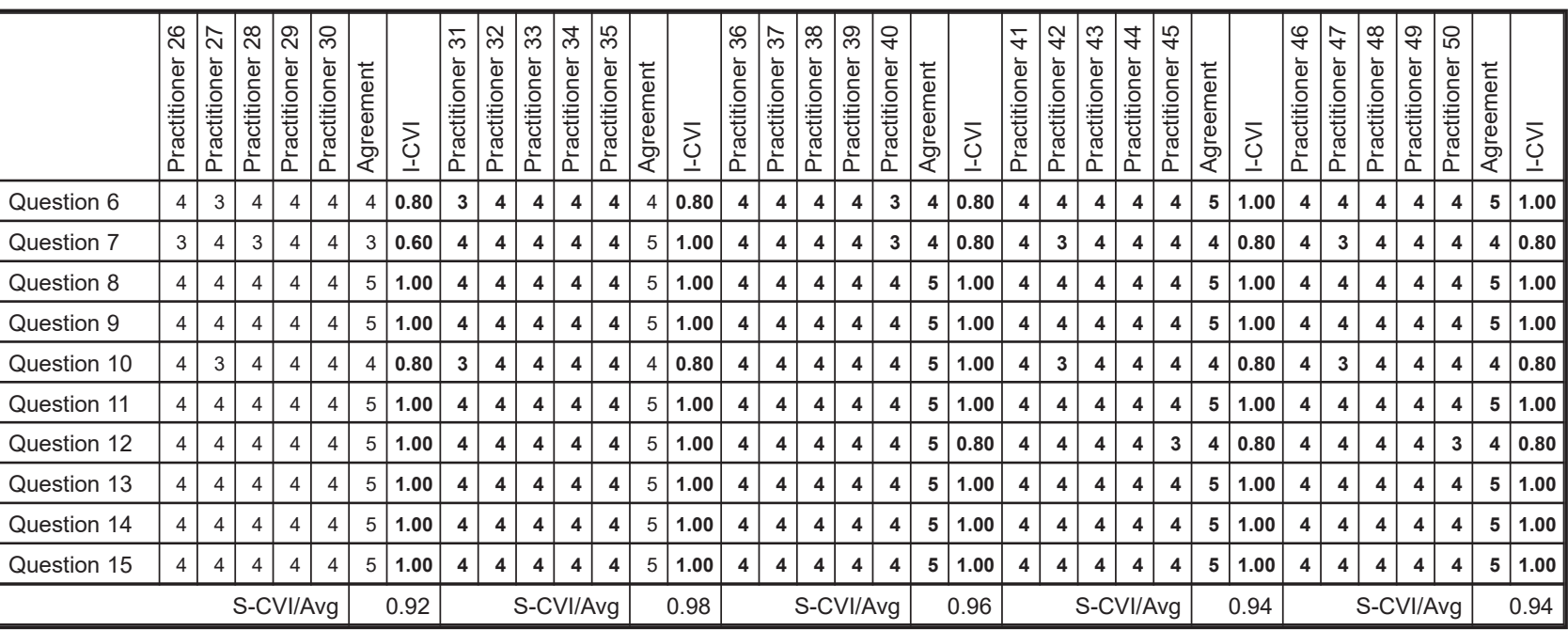

\begin{tabular}{|c|c|c|c|c|c|c|c|c|c|c|c|c|c|c|c|c|c|c|c|c|c|c|c|c|c|c|c|c|c|c|c|c|c|c|c|}
\hline & 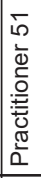 & 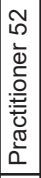 & 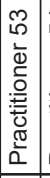 & 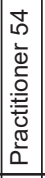 & 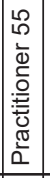 & 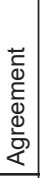 & $\underset{1}{>}$ & 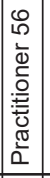 & 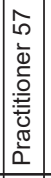 & 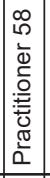 & 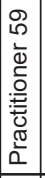 & 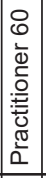 & 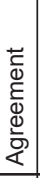 & $\underset{1}{\substack{1\\
}}$ & 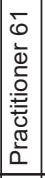 & 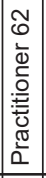 & 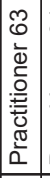 & 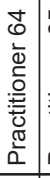 & 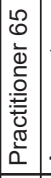 & 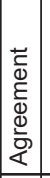 & $\begin{array}{l}> \\
\\
1\end{array}$ & 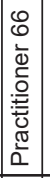 & 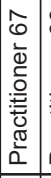 & 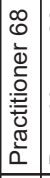 & 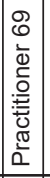 & 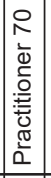 & 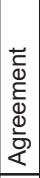 & $\underset{1}{>}$ & 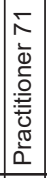 & 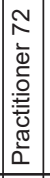 & 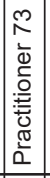 & 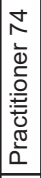 & 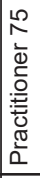 & 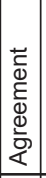 & $\underset{\substack{>\\
}}{ }$ \\
\hline Question 6 & 4 & 3 & 4 & 4 & 4 & 4 & 0.80 & 3 & 4 & 4 & 4 & 4 & 4 & 0.80 & 4 & 4 & 4 & 4 & 3 & 4 & 0.80 & 4 & 4 & 4 & 4 & 4 & 5 & 1.00 & 4 & 4 & 4 & 4 & 4 & 5 & 1.00 \\
\hline Question 7 & 3 & 4 & 3 & 4 & 4 & 3 & 0.60 & 4 & 4 & 4 & 4 & 4 & 5 & 1.00 & 4 & 4 & 4 & 4 & 3 & 4 & 0.80 & 3 & 4 & 4 & 4 & 4 & 4 & 0.80 & 3 & 4 & 4 & 4 & 4 & 4 & 0.80 \\
\hline Question 8 & 4 & 4 & 4 & 4 & 4 & 5 & 1.00 & 4 & 4 & 4 & 4 & 4 & 5 & 1.00 & 4 & 4 & 4 & 4 & 4 & 5 & 1.00 & 4 & 4 & 4 & 4 & 4 & 5 & 1.00 & 4 & 4 & 4 & 4 & 4 & 5 & 1.00 \\
\hline Question 9 & 4 & 4 & 4 & 4 & 4 & 5 & 1.00 & 4 & 4 & 4 & 4 & 4 & 5 & 1.00 & 4 & 4 & 4 & 4 & 4 & 5 & 1.00 & 4 & 4 & 4 & 4 & 4 & 5 & 1.00 & 4 & 4 & 4 & 4 & 4 & 5 & 1.00 \\
\hline Question 10 & 4 & 3 & 4 & 4 & 4 & 4 & 0.80 & 3 & 4 & 4 & 4 & 4 & 4 & 0.80 & 4 & 4 & 4 & 4 & 4 & 5 & 1.00 & 4 & 4 & 4 & 4 & 4 & 4 & 1.00 & 4 & 4 & 4 & 4 & 4 & 5 & 1.00 \\
\hline Question 11 & 4 & 4 & 4 & 4 & 4 & 5 & 1.00 & 4 & 4 & 4 & 4 & 4 & 5 & 1.00 & 4 & 4 & 4 & 4 & 4 & 5 & 1.00 & 4 & 4 & 3 & 4 & 4 & 5 & 0.80 & 4 & 4 & 4 & 4 & 4 & 5 & 1.00 \\
\hline Question 12 & 4 & 4 & 4 & 4 & 4 & 5 & 1.00 & 4 & 4 & 3 & 4 & 4 & 4 & 0.80 & 4 & 4 & 4 & 4 & 4 & 5 & 1.00 & 4 & 4 & 4 & 4 & 4 & 4 & 1.00 & 4 & 4 & 4 & 4 & 4 & 5 & 1.00 \\
\hline Question 13 & 4 & 4 & 4 & 4 & 4 & 5 & 1.00 & 4 & 4 & 4 & 4 & 4 & 5 & 1.00 & 4 & 4 & 4 & 4 & 4 & 5 & 1.00 & 4 & 3 & 4 & 4 & 4 & 5 & 0.80 & 4 & 3 & 4 & 4 & 4 & 4 & 0.80 \\
\hline Question 14 & 4 & 4 & 4 & 4 & 4 & 5 & 1.00 & 4 & 4 & 4 & 4 & 4 & 5 & 1.00 & 4 & 4 & 4 & 4 & 4 & 5 & 1.00 & 4 & 4 & 4 & 4 & 4 & 5 & 1.00 & 4 & 4 & 4 & 4 & 4 & 5 & 1.00 \\
\hline Question 15 & 4 & 4 & 4 & 4 & 4 & 5 & 1.00 & 4 & 4 & 4 & 4 & 4 & 5 & 1.00 & 4 & 4 & 4 & 4 & 4 & 5 & 1.00 & 4 & 4 & 4 & 4 & 4 & 5 & 1.00 & 4 & 4 & 4 & 4 & 4 & 5 & 1.00 \\
\hline \multicolumn{6}{|c|}{ S-CVI/Avg } & & 0.92 & \multicolumn{5}{|c|}{ S-CVI/Avg } & & 0.94 & \multicolumn{5}{|c|}{ S-CVI/Avg } & & 0.96 & \multicolumn{5}{|c|}{ S-CVI/Avg } & & 0.94 & \multicolumn{5}{|c|}{ S-CVI/Avg } & \multicolumn{2}{|r|}{0.96} \\
\hline
\end{tabular}

Note: I-CVI - Item wise Content Validity Index; S-CVI - Scale Level Content Validity Index; I-CVI = (agreed item)/(number of experts); Scale level content validity index S-CVI - the average of the I-CVI score of all items; S-CVI/Ave = (sum of I-CVI scores)/(number of items); item level content validity index I-CVI - the proportion of experts giving items a relevance rating. 


\begin{tabular}{|c|c|c|c|c|c|c|}
\hline \multicolumn{7}{|c|}{ U STATISTICS FOR ALL THREE SESSIONS AT 5\% SIGNIFICANCE LEVEL } \\
\hline Sessions in comparison & $\begin{array}{c}\text { Sum } \\
\text { of ranks R }\end{array}$ & $\frac{\mathbf{n}(\mathbf{n}+\mathbf{1})}{\mathbf{2}}$ & $\mathbf{U}=\mathbf{R}-\frac{\mathbf{n}(\mathbf{n}+\mathbf{1})}{\mathbf{2}}$ & $\begin{array}{c}\text { Critical U } \\
\text { at } \mathbf{p}<\mathbf{0 . 5}\end{array}$ & Comment \\
\hline Session 1 & Session 2 & 24.5 & 15 & 9.5 & 2 & $\begin{array}{c}\text { Populations are not } \\
\text { significantly different }\end{array}$ \\
\hline Session 1 & Session 3 & 23.5 & 15 & 8.5 & 2 & $\begin{array}{c}\text { Populations are not } \\
\text { significantly different }\end{array}$ \\
\hline Session 2 & Session 3 & 26.5 & 15 & 11.5 & 2 & $\begin{array}{c}\text { Populations are not } \\
\text { significantly different }\end{array}$ \\
\hline
\end{tabular}

belong to a similar population. We used Mann \& Whitney statistics ' $U$ ' to evaluate if all three sessions provided a similar response. Hypothesis created were as follows.

$\mathrm{H}_{0}$ : Distributions of both populations, to whom S-CVIs of any two sessions belong, are equal.

$\mathrm{H}_{1}$ : Distributions are not equal.

Table 4 illustrates the critical values of $U$ to find out the difference being significant or not. The values of $U$ lie in the acceptance region, so there is no evidence to reject the $\mathrm{H}_{0}$ hence all three sessions gave the same response.

\section{RESULT AND DISCUSSION}

Establishing face and content validity is a systematic process. The participants were briefed about the competency framework and its development methodology. The first question was to evaluate the acceptability chances of the competency framework in the textile sector of Pakistan. The second question identifies the areas of implementation and further research. The third question evaluates the confidence on the framework development. Last two questions were to face validate the framework. Table 5 further elaborates and analyses the collected data; the average face validation score is $99 \%$.

The last ten questions were to assess the content validity of the framework on a 5-point rating scale. 75 participants were distributed in 3 sessions so that they can be presented the competency framework for replying to the questionnaire. Each session was further divided into a group of 5 to facilitate any discussion. I-CVI for each question was calculated and then S-CVI. With S-CVI from 0.92 to 1.00, the instrument had good content validity. The results indicate that the framework developed and presented for this study is a reliable instrument for adopting in human resource life cycle within the textile sector of Pakistan. It was further tested that S-CVI responses of different sessions are not significantly different.

\section{CONCLUSION}

Human resource competencies are essential for meeting performance standards and achieving important results. Competencies are easy to apply if these are presented in a scientifically designed framework involving experts from various professional disciplines. Practitioners of the industry, where the framework is planned to be implemented, should validate the outlook and contents of the framework.

Feedback of the practitioners from different professions working in the textile sector provided enough evidence that the framework in focus ranks on the higher side in terms of presentation. Approximately, $99 \%$ respondents ranked it on two higher choices. The framework stands a good chance of implementation at various human resource stages. The calculated content validation index for each item of the framework and average of all ranging from 0.92 to 1.00 , qualify the entrails of this instrument.

The following inferences were also apparent from the study: Firstly, the validation provided a stable and

Table 5

\begin{tabular}{|c|l|l|c|c|}
\hline \multicolumn{5}{|c|}{ ANALYSIS OF THE RESPONSES AGAINST FIRST FIVE QUESTIONS } \\
\hline Question & \multicolumn{1}{|c|}{ Content } & \multicolumn{1}{|c|}{ Purpose } & $\begin{array}{c}\text { Total of First Two Choices } \\
\text { out of 75 }\end{array}$ & $\%$ 7age \\
\hline 5 & $\begin{array}{l}\text { Comprehensiveness of } \\
\text { the Framework }\end{array}$ & Face Validity & 75 & 98.66 \\
\hline 4 & $\begin{array}{l}\text { Presentation of the } \\
\text { Framework }\end{array}$ & Face Validity & 74 & 100.00 \\
\hline 3 & $\begin{array}{l}\text { lonfidence on the devel- } \\
\text { opment methodology }\end{array}$ & $\begin{array}{l}\text { Confidence on the Framework } \\
\text { contents }\end{array}$ & 98.66 \\
\hline 2 & $\begin{array}{l}\text { Preferred area(s) of } \\
\text { implementation }\end{array}$ & For further research & $\begin{array}{l}\text { Performance evaluation, training } \\
\text { needs analysis, recruitment (72) }\end{array}$ & 96.00 \\
\hline 1 & $\begin{array}{l}\text { Support of generic } \\
\text { Framework }\end{array}$ & $\begin{array}{l}\text { Specific industry supports the idea } \\
\text { of a generic Framework or not }\end{array}$ & 74 & 98.66 \\
\hline
\end{tabular}


appropriate presentation of the framework related to generic competencies specifically in the textile sector. Secondly, it gives professionals a better idea of what competencies they should look for when dealing with the human resource at various stages. Hence, the findings will help improve professional development opportunities essential for overcoming the perceived deficiency in human resource management areas.
These findings could further be verified in settings like other industries or trades, larger geography, more diverse and assorted groups.

This study limits the validation to face and content; further research can validate the framework while applying to areas of human resource management for example, recruitment, performance evaluation, career development, training needs identification, promotion and deployment.

\section{REFERENCES}

[1] Sebastian, C.I., et al., Comparative analysis of small and medium enterprises organizational performance in clothing industry, In: Industria Textila, 2017, 68, 2, 156-162, https://doi.org/10.35530/IT.068.02.1305

[2] Tripathi, K., Agrawal, M., Competency Based Management in Organizational Context: A Literature Review., In: Global Journal of Finance and Management, 2014, 6, 4, 349-356

[3] Chouhan, V.S., Srivastava, S., Understanding Competencies and Competency Modeling - A Literature Survey, In: IOSR Journal of Business and Management, 2014, 16, 1, 14-22

[4] Parry, S.B., The quest for competencies. Training, 1996, 33, 7, 48-54

[5] Girneata, A., et al., Performance management practices in Romanian textile and clothing companies, In: Industria Textila, 2015, 66, 2, 108-113

[6] Stevens, A., Critical Review of the Science and Practice of Competency Modeling, In: Human Resource Development Review, 2013, 12, 1, 86-107

[7] Suhairom, N., et al., The development of competency model and instrument for competency measurement: The research methods, In: Procedia - Social and Behavioral Sciences, 2014, 152, 1300-1308

[8] Garavan, T., McGuire, D., Competencies and Workplace Learning: Some Reflection on the Rhetoric and the Reality, In: Journal of Workplace Learning, 2001, 13, 4, 144-164

[9] Robson, R., Poltrack, J., Using Competencies to Map Performance across Multiple Activities, In: Interservice/Industry Training, Simulation and Education Conference, Orlando, Florida, 2017, 1-12

[10] Tay Chinyi, H., et al., People Performance Competency Assessment - An Objective Psychometric Measure, In: International Journal of Research in Business Management, 2017, 5, 4, 1-18

[11] Geoff, R., et al., Development and Validation of a Customized Competency-Based Questionnaire, In: CrossCultural Management, 2012, 19, 1, 90-103

[12] Tudor, L., Change in Textile and Clothing Industry, In: Industria Textila, 2018, 69, 1, 37-43, http://doi.org/ 10.35530/IT.069.01.1449

[13] Nastase, M., et al., The specific elements of strategic human resources management for competitive business development, In: Industria Textila, 2019, 70, 6, 579-586, http://doi.org/10.35530/IT.070.06.1749

[14] Lam Kim W., et al., Evaluating the Face and Content Validity of an Instructional Technology Competency Instrument for University Lecturers in Malaysia, In: International Journal of Academic Research in Business \& Social Sciences, 2018, 8, 5, 367-385

[15] Israel, G.D., Determining Sample Size, PEOD6, Institute of Food and Agricultural Sciences (IFAS), University of Florida, 2003

\section{Authors:}

\section{MUHAMMAD MIDHAT ALI, SHEHERYAR MOHSIN QURESHI}

N.E.D. University of Engineering and Technology, Department of Industrial and Manufacturing Engineering, University Road, Karachi-75270, Pakistan e-mail: midhat@neduet.edu.pk

\section{Corresponding author:}

SHEHERYAR MOHSIN QURESHI

e-mail: sheheryar@neduet.edu.pk 